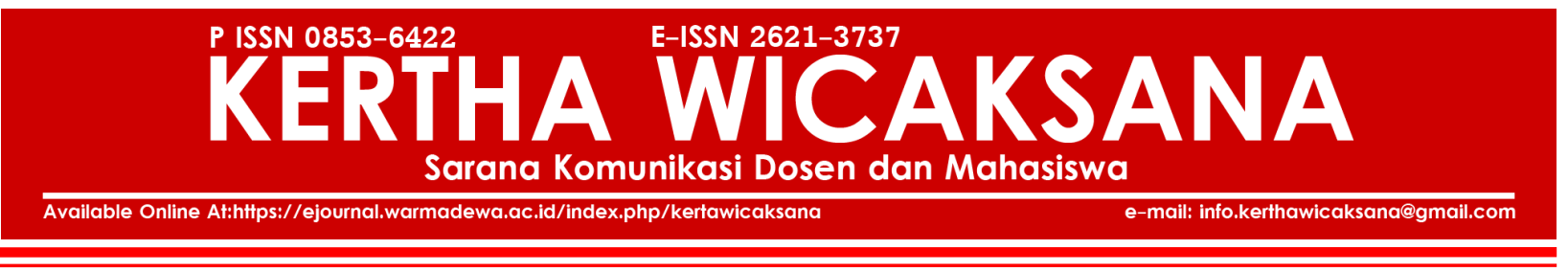

\title{
Politik Hukum Pemberantasan Prostitusi Online Terkait Kriminalisasi Pekerja Seks Komersial dan Pengguna
}

\author{
I Dewa Gede Dana Sugama* dan Diah Ratna Sari Hariyanto \\ Fakultas Hukum Universitas Udayana, Denpasar, Bali-Indonesia \\ dewasugama@ymail.com
}

Published: 25/07/2021

How To Cite:

Sugama, I. D. G. D., \& Hariyanto, D. R. S. (2021). Politik Hukum Pemberantasan Prostitusi Online Terkait Kriminalisasi Pekerja Seks Komersial dan Pengguna. KERTHA WICAKSANA: Sarana Komunikasi Dosen dan Mahasiswa. 15(2). Pp 158-168. https://doi.org/10.22225/kw.15.2.2021.158-168

\begin{abstract}
Abstrak
Kasus prostitusi menjadi fenomena yang selalui mewarnai penegakan hukum di Indonesia. Modus operandinyapun kian berkembang, yang saat ini marak adalah prostitusi online. Meskipun prostitusi telah diatur dalam KUHP dan terkait transaksi online bisa ditemukan dalam UU ITE namun, faktanya kasus prostitusi online sulit untuk diberantas. Hal ini dikarenakan hanya mucikari yang bisa dipertanggungjawabkan secara pidana, sedangkan PSK (Pekerja Seks Komersial) dan pengguna jasa prostitusi online tidak bisa dipertanggungjawabkan secara pidana. Hal ini tentu perlu direkonstruksi kembali sehingga penting untuk dikaji mengenai pengaturan prostitusi online dan politik hukum pemberantasan prostitusi, khususnya terkait kriminalisasi PSK (Pekerja Seks Komersial) dan pengguna jasa prostitusi online. Penelitian ini menggunakan jenis penelitian hukum normatif. Hasil studi menunjukkan bahwa KUHP tidak mengatur pemidanaan terhadap PSK dan Pengguna jasa prostitusi online, sehingga tidak bisa dipertanggungjawabkan secara pidana. Apabila dikaji peraturan di luar KUHP terkait prostitusi online, PSK dan pengguna jasa dapat dijerat dengan menggunakan UU ITE, namun aturan ini masih bersifat umum yang mengatur larangan yang melanggar kesusilaan. Pengaturan prostitusi juga dapat ditemukan dalam Peraturan Daerah (Perda), namun tidak semua daerah memiliki atau mengeluarkan Perda tentang Prostitusi, sehingga keberlakuannya terbatas pada territorial. Politik hukum yang dapat diambil adalah dengan pembaharuan hukum pidana dengan mensinergikan konsep rancangan KUHP yakni dengan mengkriminalisasi dan mengatur pemberian ancaman pidana terhadap PSK dan pengguna jasa prostitusi online agar bisa dipertanggungjawabkan secara pidana (penalisasi).
\end{abstract}

Kata Kunci: Politik Hukum; Prostitusi Online; Kriminalisasi

\begin{abstract}
Prostitution cases have emerged as a phenomenon having continuously loaded with law enforcement actions in Indonesia; the modus operandi is getting developed over time. The case that is currently trending is the case of online prostitution. Although prostitution cases have been set forth in the Criminal Code and online transactionrelated legal provisions can be found in the Electronic Information and Transaction Law (ITE Law), however, online prostitution cases are in fact difficult to eradicate. This is due to the condition that only the procurers or procuresses can be held liable for the acts, while sex workers (commercial sex workers) and the online prostitution service users cannot. This indicates that the prostitution-related legal arrangement needs to be reconstructed, and for that, the present study has an urgent force to be carried out to review the online prostitution regulations as well as the legal politics to eradicate prostitution, particularly regarding the criminalization of sex workers (commercial sex workers) and the online prostitution service users. This study applies a normative law research method design. The results of the study show that the Criminal Code does not regulate the conviction of commercial sex workers and online prostitution service users, so they cannot be held criminally liable for the act. If the online prostitution-related regulations outside those in the Criminal Code are examined further, sex workers and their service users can be charged with the ITE Law, but the rule is still general in nature - regulating prohibitions that violate decency. Regulations on prostitution can also be found in Regional Regulations (Perda), but not all regions have or issue the regulations on Prostitution, so their enforcement is limited to the territory. The political law that can be learned from this fact is the reform of criminal law through the synergy of the draft of
\end{abstract}


Criminal Code concept through criminalization and the provision of criminal threats against commercial sex workers and the online prostitution service users so that they can be held criminally liable for (penalization).

Keywords: Political Law; Online Prostitution; Criminalization

\section{PENDAHULUAN}

Kasus prostitusi, pelacuran, atau persundalan telah menjadi fenomena yang selalu mewarnai penegakan hukum di Indonesia. Frank E. Hagan menyatakan bahwa prostitusi adalah praktik hubungan seksualitas dengan pengabaian situasi emosional yang dilakukan dengan siapapun dan secara berbayar (Hagan, 2013). Penegakan hukum pemberantasan prostitusi telah dilakukan, namun sampai saat ini kasus prostitusi masih kerap terjadi dan meresahkan masyarakat Indonesia. Modus operandinya pun kian berkembang, yang marak saat ini adalah prostitusi online. Banyak kasus prostitusi online yang terjadi di Indonesia, seperti misalnya kasus VA pada tahun 2019, kasus VS tahun 2020 dan kasuskasus lainnya yang bisa ditemukan disemua kalangan. Kasus ini menunjukkan bahwa pemberantasan prostitusi belum berhasil dilakukan.

Penegak hukum kerap menggunakan pasal dalam KUHP dan dihubungkan dengan UU No. 19 Tahun 2016 Tentang Perubahan Atas UndangUndang Nomor 11 Tahun 2008 Tentang Informasi dan Transaksi Elektronik dan UU Perdagangan orang. KUHP tidak mengatur secara khusus tentang prostitusi. UU ITEpun hanya mengatur mengenai perbuatan yang melanggar kesusilaan melalui transaksi elektronik, UU Perdagangan orang juga tidak tepat penggunaannya. Meskipun prostitusi telah diatur dalam KUHP dan transaksi online bisa ditemukan dalam UU ITE, namun faktanya kasus prostitusi online sulit untuk diberantas. Hal ini dikarenakan dalam KUHP hanya mucikari yang bisa dipertanggungjawabkan secara pidana, sedangkan PSK (Pekerja Seks Komersial) dan pengguna jasa prostitusi online tidak bisa dipertanggungjawabkan secara pidana. Hal ini tentu perlu direkonstruksi.

Politik hukum sebagai kebijakan penyelenggara negara yang bersifat mendasar dalam menentukan arah, bentuk, maupun isi dari hukum yang akan dibentuk dan tentang apa yang dijadikan kriteria untuk menghukumkan sesuatu perlu dilakukan (Syaukani, 2010). Hal ini penting dalam konteks pembaharuan hukum pidana kedepan, sehingga pemberantasan prostitusi online dapat efektif dilakukan. Politik hukum harus dilakukan mengingat prostitusi kini menjadi ancaman bagi masyarakat di Indonesia.

Prostitusi dikaji dari budaya masyarakat Indonesia tentu menjadi perbuatan yang dicela. Tidak hanya dari aspek kesusilaan, prostitusi juga dianggap meresahkan masyarakat karena banyak dampak atau kerugian yang dirasakan. Salah satu yang membahayakan adalah dapat menimbulkan berbagai macam penyakit kelamin, yang paling ditakuti adalah HIV AIDS yang menular dan mengakibatkan banyaknya kematian. Peraturan terkait prostitusi masih lemah sehingga perlu dilakukan rekonstruksi hukum berupa pembaharuan hukum pidana yang mengatur prostitusi online, sebagaimana yang menjadi tujuan utama dalam studi ini. Hal inilah yang menjadi studi ini urgen untuk dilakukan sehingga prostitusi online bisa diberantas.

PSK dan pengguna jasa prostitusi perlu dikriminalisasikan untuk memberikan efek jera, sehingga penelitian ini penting yang bermanfaat untuk merumuskan politik hukum ke depan. Penelusuran pengaturan prostitusi online di Indonesia bermanfaat untuk mengetahui hukum yang berlaku dalam pemberantasan prostitusi online di Indonesia. Politik hukum berupa pembaharuan hukum merupakan langkah yang tepat dilakukan sebagai langkah pemberantasan prostitusi online. Hasil penelitian ini dapat menghasilkan rumusan pengaturan mengenai prostitusi online yang dapat menjerat PSK dan pengguna jasa prostitusi, sehingga pemberantasan prostitusi online dapat efektif dilakukan. Penelitian dengan upaya pemberantasan prostitusi online ni akan sangat bermanfaat sebagai upaya perlindungan bagi masyarakat dan membantu penegak hukum dalam penegakan hukum prostitusi online.

Fenomena bahwa prostitusi kian marak terjadi dan lemahnya perangkat hukumnya menjadikan tulisan ini urgen dan menarik untuk dikaji sehingga penulis menulis artikel yang berjudul, "Politik Hukum Pemberantasan Prostitusi Online Terkait Kriminalisasi Pekerja Seks Komersial dan Pengguna". Tulisan ini mengkaji permasalahan terkait pengaturan prostitusi online dan politik hukum pemberantasan prostitusi, khususnya terkait kriminalisasi PSK (Pekerja Seks Komersial) dan pengguna jasa prostitusi online di 
Politik Hukum Pemberantasan Prostitusi Online Terkait Kriminalisasi Pekerja Seks Komersial dan Pengguna

Indonesia, dengan tujuan mengetahui, menganalisis, dan menemukan pengaturan dan politik hukum pemberantasan prostitusi online dengan upaya kriminalisasi.

\section{METODE}

Studi ini adalah penelitian hukum normatif yang mengkaji mengenai Politik Hukum Pemberantasan Prostitusi Online Terkait Kriminalisasi PSK (Pekerja Seks Komersial) dan Pengguna Jasa Prostitusi di Indonesia, yang berawal dari permasalahan norma terkait pertanggungjawaban pidana terhadap PSK dan pengguna jasa prostitusi. Penelitian ini menggunakan pendekatan kasus, pendekatan perundang-undangan, konseptual, pendekatan sejarah, dan perbandingan. Bahan hukum primer, sekunder, dan tersier/tertier yang digunakan dalam penelitian ini kemudian diidentifikasi, diklasifikasi dan dikumpulkan secara sistematis dengan menggunakan metode bola salju (snow ball method). Bahan hukum selanjutnya dianalisis dengan menggunakan teknik deskripsi/deskriptif, teknik komparatif, teknik evaluasi/evaluatif, teknik interpretasi, teknik konstruksi, dan teknik argumentasi/argumentatif.

\section{HASIL DAN PEMBAHASAN}

\section{Pengaturan Prostitusi online di Indonesia}

Setelah diidentifikasi, diklasifikasi dan diinventarisasi dapat ditemukan beberapa peraturan perundang-undangan dari KUHP sampai aturan yang lebih rendah yakni perda yang mengatur mengenai prostitusi (prostitusi online). Peraturan Perundang-undangan yang mengatur mengenai prostitusi online di Indonesia diantaranya yakni:

\section{Kitab Undang-Undang Hukum Pidana}

Ketentuan terkait prostitusi dapat ditemukan dalam Pasal 296 KUHP dan Pasal 506 KUHP. Pasal 296 KUHP pada intinya mengatur orang yang dengan sengaja menghubungkan atau memudahkan perbuatan cabul dan dijadikan sebagai pekerjaan atau kebiasaan, yang sering kita sebut dengan mucikari/germo. Pasal 296 KUHP memberikan ancaman pidana penjara maksimal 1 tahun 4 bulan dan denda paling banyak seribu rupiah (dengan penyesuaian mata uang) bagi para pelanggarnya. Pasal 506 KUHP mengatur tentang orang yang menarik keuntungan dari wanita yang melakukan cabul sebagai mata pencarian dengan ancaman pidana maksimal 1 tahun kurungan.
Pasal 296 KUHP merupakan pasal yang mengatur tentang kejahatan kesusilan sebagai kejahatan yang dengan kesengajaan menyebabkan atau memudahkan dilakukannya tindakantindakan melanggar kesusilaan dengan orang ketiga sebagai mata pencaharian atau kebiasaan yang sering disebut persundalan atau prostitusi. Secara substantif, ketentuan pasal 296 KUHP ini ditujukan oleh mucikari sebagai penyedia jasa (Mucikari menurut KBBI berarti induk semang bagi seorang perempuan yang melacur; germo). (kamuslengkap.com).

Berdasarkan hal ini mucikari atau yang dikenal dengan germo sebagai penyedia jasa prostitusilah yang dapat dijerat dengan Pasal 296 KUHP.

Soesilo menyatakan bahwa Pasal 296 KUHP digunakan untuk memberantas kejahatan yang dilakukan oleh orang-orang yang mengadakan/ menyediakan atau menjalankan bordil atau tempat-tempat pelacuran. Pasal ini dapat dikenakan jika dapat dibuktikan bahwa perbuatannya tersebut telah menjadi mata pencaharian (dengan adanya pembayaran) atau kebiasaan (dilakukan lebih dari satu kali). Perbuatan cabul dalam pasal 296 KUHP ini termasuk kegiatan atau perbuatan persetubuhan. Orang yang dapat dikenakan pasal ini adalah orang yang menyediakan rumah atau kamar (dengan pembayaran atau yang lebih dari satu kali) kepada perempuan dan laki-laki untuk melacur (bersetubuh atau melepaskan nafsu kelaminnya dengan orang lain) ditempat tersebut. Pada umumnya disediakan pula tempat tidur. (Soesilo, 1976).

Orang yang menyediakan rumah bordil atau tempat pelacuran ini dapat disebut dengan mucikari atau germo. Dalam perkembangannya saat ini, mucikari atau germo tidak harus menyediakan tempat pelacuran. Ketika seseorang dengan sengaja sudah menghubungkan atau memudahkan perbuatan cabul dan juga persetubuhan oleh orang lain dengan orang lain, dan menjadikannya sebagai pencarian atau kebiasaan dengan mendapat imbalan atau pembayaran maka ia sudah disebut mucikari atau germo.

Pasal 506 KUHP adalah pasal yang mengatur tentang pelanggaran ketertiban umum. Dalam penjelasannya R. Soesilo dalam pasal ini menyatakan bahwa mucikari (souteneur) adalah makelar cabul, sebagai yang menolong, mencarikan pelanggan dan mucikari akan 
mendapatkan bagian (pembayaran) dari hasil pelacuran tersebut. (Ibid:259) Pasal 506 KUHP ini jika dikaji hanya dapat dikenakan kepada mucikari atau germo saja sebagai pihak atau orang yang menarik keuntungan dari perbuatan cabul seorang wanita dan menjadikannya sebagai mata pencarian.

(Sianturi, 1983) juga menegaskan bahwa apabila pasal 285-294 KUHP kecuali pasal 290 ke-3 KUHP adalah kejahatan yang subyeknya langsung terlibat sebagai pelaku pencabulan, maka pasal 295-297 dan 506 subyeknya tidak terlibat langsung melainkan hanya sebagai penghubung saja. Pasal 296 KUHP diatur untuk memerangi pencabulan (termasuk persetubuhan tercela) karena dalam prakteknya terutama di kota -kota besar apalagi yang terletak di daerah tempat -tempat maksiat dan membatasi tempatnya saja. Apabila tempat-tempat ini ditiadakan maka tempat maksiat itu akan menyebar dimana-mana sehingga lebih merusak ingkungan, disamping sulit untuk mengawasi dan menanggulangi penyakit yang dibawanya. Si petindak dalam pasal 296 KUHP ini dapat laki-laki maupun perempuan yang sering disebut germo, sedangkan pelaku pencabulan yang juga mencakup persetubuhan dalah orang dewasa.

Delik dalam pasal 296 KUHP ini adalah delik dengan kesengajaan, karena menjadikannya sebagai pencaharian atau kebiasaan. Unsur tindakannya adalah menjadikannya penghubung pencabulan antara sesama dewasa sebagai pencaharian atau kebiasaan. Penghungan pencabulan ini dapat dilakukan dengan menggerakkan atau memudahkan dilakukannya perbuatan cabul antara orang dewasa dengan orang dewasa lainnya. Pegertian memudahkan dalam hal ini termasuk juga menyediakan tempat rendevouz (jumpa/bertemu) misalnya hotel, motel, dan lain-lain yang oleh pemilik atau pengusaha hotel tersebut mengetahui bahwa telah terjadi pencabulan di hotel tersebut. Perbedaan hotel dengan tempat rendevouz adalah bahwa di tempat bordil disediakan beberapa wanita (atau mungkin juga banci/gigolo) untuk melayani tamu yang datang, sedangkan tempat rendevouz tidak menyediakan seseorang untuk melayani tamu tersebut melainkan tamu itu datang dengan membawa pasangannya sendiri. Delik ini dipandang sempurna (voltooid) apabila yang digerakkan atau dimudahkan itu sudah mulai melakukan pencabulan. (Ibid)

Berdasarkan kajian terhadap Pasal 296 dan
506 KUHP dapat diketahui bahwa Pasal 296 dan 506 KUHP hanya dapat menjerat atau dikenakan kepada mucikari atau germo sebagai penyedia jasa prostitusi. PSK dan pengguna jasa prostitusi tidak dapat dijerat atau dikenakan Pasal 296 dan 506 KUHP, sehingga dapat dikatakan bahwa KUHP tidak mengatur terkait pertanggungjawaban prostitusi terhadap PSK dan pelanggan atau pengguna jasa prostitusi. Hanya mucikari yang bisa dipertanggungjawabkan secara pidana. Secara substantif, KUHP juga hanya mengatur terkait perbuatan prostitusi dalam bentuk pokok, tidak mengatur mengenai cara atau sarana prostitusi. KUHP tidak mengatur mengenai prostitusi online, namun Pasal 296 dan 506 KUHP dapat dikenakan kepada mucikari yang menyediakan jasa prostitusi yang dilakukan secara online. Mucikari dapat dipertanggungjawabkan secara pidana ketika melakukan atau menyediakan, menghubungkan, atau memudahkan perbuatan prostitusi online.

Dalam prakteknya PSK dan pengguna jasa prostitusi sering dikenakan atau dijerat dengan pasal 284 KUHP yang mengatur tindak pidana perzinahan jika pengguna jasa prostitusi online berstatus telah menikah. Pasal 284 KUHP ini bukanlah pasal tentang prostitusi, namun merupakan pasal perzinahan sehingga tidak tepat dikatakan sebagai dasar hukum prostitusi dalam KUHP. KUHP hanya mengatur terkait prostitusi yang hanya dapat dipertanggungjawabkan secara pidana oleh mucikari saja, sedangkan PSK dan pengguna jasa tidak dapat dipertanggungjawabkan secara pidana dalam kasus prostitusi atau prostitusi online.

Oksidelfa Yanto menulis bahwa sebenarnya Indonesia tela memiliki aturan untuk melarang kegiatan prostitusi, hanya saja aturan-aturan tersebut belum memberikan ketegasan, khususnya penindakan bagi PSK dan pengguna jasa prostitusi itu sendiri. Tidak ada pasal dalam KUHP untuk menjerat PSK maupun pengguna. Penindakan terhadap tindak pidana prostitusi hanya dapat diberikan untuk menjerat muncikari, yakni Pasal 296 dan Pasal 506 KUHP. Pasal 296 dan Pasal 506 KUHP jika dicermati hanya mengatur mengenai tindak pidana dalam hal seseorang mengambil keuntungan ataupun menghubungkan seseorang dengan orang lain untuk melakukan prostitusi. Pasal ini adalah pasal yang mengatur tindakan yang dilakukan oleh muncikari, bukan PSK atau bahkan penggunanya. (Yanto, 2016) Hal-hal ini menunjukkan bahwa KUHP belum mampu memberantas prostitusi 
online karena hanya mengatur pemidanaan terhadap mucikari saja.

Undang-Undang ITE Yakni UU No. 11 Tahun 2008 Tentang Informasi dan Transaksi Elektronik jo. Undang-Undang RI No. 19 Tahun 2016 Tentang Perubahan Atas Undang-Undang Nomor 11 Tahun 2008 Tentang Informasi dan Transaksi Elektronik

Prostitusi online tentunya dapat dijerat atau dikenakan dengan pasal yang diatur dalam UU No. 11 Tahun 2008 Tentang Informasi dan Transaksi Elektronik jo. Undang-undang RI No. 19 Tahun 2016 Tentang Perubahan Atas UndangUndang Nomor 11 Tahun 2008 Tentang Informasi dan Transaksi Elektronik (Selanjutnya disebut UU ITE) karena dalam sistem online digunakan sarana atau media elektronik. Prostitusi online dapat dikenakan atau dijerat dengan menggunakan Pasal 45 Ayat (1) UU ITE dengan pidana penjara maksimal 6 (enam) tahun penjara dan/atau denda maksimal satu miliar rupiah bagi orang yang sengaja dan tanpa hak melakukan pendistribusian dan/atau mentransmisikan dan/atau menjadikan/membuat dapat diaksesnya Informasi Elektronik dan/atau Dokumen Elektronik yang bermuatan melanggar kesusilaan yang sebagaimana diatur dalam Pasal 27 ayat (1) UU ITE. Aturan ini memang bukan spesifik mengatur tentang prostitusi online namun dapat digunakan sebagai dasar hukum prostitusi online, karena prostitusi adalah perbuatan atau kejahatan kesusilaan.

Apabila dikaji secara substantif dan kajian unsur-unsur dalam Pasal 45 ayat (1) UU ITE dapat diketahui bahwa pasal ini berlaku secara umum dan tanpa diskriminasi yang dapat berlaku atau dikenakan terhadap semua orang yang dengan sengaja dan tanpa hak mendistribusikan dan/atau mentransmisikan dan/atau membuat dapat diaksesnya Informasi Elektronik dan/atau Dokumen Elektronik yang memiliki muatan yang melanggar kesusilaan. Aturan ini nampaknya hanya dapat berlaku terbatas hanya bagi orang yang sengaja dan tanpa hak mendistribusikan, mentransmisikan, menjadikan/membuat dapat diaksesnya perbuatan prostitusi melalui informasi elektronik/dokumen elektronik saja, sehingga bagi PSK, Mucikari, dan pengguna jasa yang tidak mendistribusikan, mentransmisikan, membuat dapat diaksesnya informasi elektronik/ dokumen elektronik yang merupakan perbuatan prostitusi maka tidak dapat dipidana berdasarkan UU ITE.

Peraturan Daerah
Pengaturan prostitusi juga dapat ditemukan dalam Peraturan Daerah (Perda), namun tidak semua daerah memiliki atau mengeluarkan Perda tentang Prostitusi. Hal ini tergantung dari kebijakan masing-masing daerah untuk mengaturnya. Beberapa contoh perda yang mengatur mengenai prostitusi adalah:

Peraturan Daerah Provinsi Daerah Khusus Ibukota Jakarta Nomor 8 Tahun 2007 Tentang Ketertiban Umum

Pasal 42 Ayat (2) Peraturan Daerah Provinsi Daerah Khusus Ibukota Jakarta Nomor 8 Tahun 2007 Tentang Ketertiban Umum mengatur bahwa menjadi Penjaja Seks Komersial, Menyuruh, memfasilitasi, membujuk, memaksa orang lain menjadi penjaja seks komersial, memakai Penjaja Seks Komersial dilarang dan diancam dengan pidana kurungan paling singkat 20 hari dan paling lama 90 hari atau denda paling sedikit $\mathrm{Rp}$. 500.000 dan paling banyak Rp. 30.000.000 sebagaimana diatur dalam Pasal 61 Ayat (2) Peraturan Daerah Provinsi Daerah Khusus Ibukota Jakarta Nomor 8 Tahun 2007 Tentang Ketertiban Umum.

Peraturan Daerah Kota Tangerang Nomor 8 Tahun 2005 Tentang Pelarangan Pelacuran

Pasal 2 Peraturan Daerah Kota Tangerang Nomor 8 Tahun 2005 Tentang Pelarangan Pelacuran yang mengatur larangan mendirikan atau mengusahakan tempat dan/atau orang untuk melakukan pelacuran, melarang perbuatan pelacuran yang berlaku juga bagi tempat hiburan, hotel, penginapan atau tempat lainnya. Apabila dilanggar dapat dikenakan pidana kurungan paling lama 3 bulan atau denda paling banyak $\mathrm{Rp}$ 15.000.000,- sebagaimana yang diatur dalam pasal 9 Perda ini. Pasal 3 dalam Perda ini juga mengatur larangan membujuk atau memaksa orang lain untuk melacur.

Peraturan Daerah Kota Malang Nomor 8 Tahun 2005 tentang Larangan Tempat Pelacuran dan Perbuatan Cabul

Pasal 2 Peraturan Daerah Kota Malang Nomor 8 Tahun 2005 tentang Larangan Tempat Pelacuran dan Perbuatan Cabul mengatur larangan tempat-tempat pelacuran dan perbuatan cabul yang dilakukan perorangan maupun yang dikoordinir oleh beberapa orang atau kelompok. Pasal 3 dalam Perda ini juga melarang menjajakan perzinahan atau pencabulan, melakukan perbuatan cabul, menjadi mucikari, dan menjadi beking yang melindungi pelacur, 
memberikan sarana dan prasarana untuk melakukan perbuatan zinah atau cabul. Apabila larangan ini dilakukan maka sesuai Pasal 4 dan 5 Peraturan Daerah ini maka perizinan tempat usaha dapat dicabut dengan segala akibat hukumnya dan Pelanggaran terhadap Pasal 2, Pasal 3 dan Pasal 4, diancam pidana kurungan maksimal 3 (tiga) bulan atau denda maksimal Rp. 10.000.000,00.

Peraturan Daerah Kabupaten Bantul Nomor 5 Tahun 2007 Tentang Larangan Pelacuran Di Kabupaten Bantul

Pasal 3 Peraturan Daerah Kabupaten Bantul Nomor 5 Tahun 2007 Tentang Larangan Pelacuran di Kabupaten Bantul mengatur larangan pelacuran dan menjadi mucikari. Pasal 4 Perda ini juga melarang menyediakan tempat/ bangunan untuk pelacuran. Pasal 5 Perda ini juga mengatur larangan melindungi kegiatan pelacuran. Terkait dengan sanksinya, Pasal 6 Perda ini mengatur penutupan kegiatan usaha yang terbukti melakukan pelacuran dan ancaman pidana berupa pidana kurungan maksimal 3 (tiga) bulan atau denda paling banyak Rp.10.000.000,00 bagi yang melanggar ketentuan Pasal 3 dan/atau Pasal 4 dan atau Pasal 5 terkait dengan perbuatan pelacuran/prostitusi.

Peraturan Daerah Kabupaten Jembrana Nomor 3 Tahun 2003 Tentang Pencegahan dan Pemberantasan Pelacuran di Kabupaten Jembrana

Pasal 6 Ayat (1) Peraturan Daerah Kabupaten Jembrana Nomor 3 Tahun 2003 Tentang Pencegahan dan Pemberantasan Pelacuran di Kabupaten Jembrana mengatur larangan perbuatan cabul dengan ancaman pidana kurungan maksimal 3 bulan atau denda maksimal Rp 5.000.000,-. Pasal 6 Ayat (2) Perda ini juga mengatur larangan menyediakan tempat-tempat pelacuran atau menampung pelacur dengan ancaman pidana kurungan maksimal 3 (tiga) bulan atau denda maksimal Rp 5.000.000,-.

Peraturan Daerah Kabupaten Daerah Tingkat II Indramyu Nomor 7 Tahun 1999 Tentang Prostitusi

Pasal 2 Peraturan Daerah Kabupaten Daerah Tingkat II Indramyu Nomor 7 Tahun 1999 Tentang Prostitusi mengatur larangan mendirikan dan atau mengusahakan serta menyediakan tempat Prostitusi. Pasal 3 Perda ini juga mengatur larangan melakukan, menghubungkan, mengusahakan dan menyediakan orang untuk melakukan Perbuatan Prostitusi. Pasal 5 Perda ini mengatur larangan membujuk/memaksa orang lain untuk melakukan Prostitusi. Pasal 6 Perda ini juga menegaskan larangan kegiatan bagi pelacur. Pasal 7 juga menegaskan bahwa pelaku prostitusi dalam Perda ini adalah baik laki-laki maupun perempuannya dikenakan sanksi sesuai dengan Pasal 9 Peraturan Daerah ini. Ketentuan pidana diatur dalam pasal 9 yang mengancam dengan pidana bagi yang melanggar Pasal 2,3,4,5,6 dan 8 ayat (1) Peraturan Daerah ini dengan Hukuman Kurungan maksimal 6 (enam) bulan atau Denda sebanyak-banyaknya Rp. 5.000.000.

\section{Peraturan Daerah Kota Denpasar Nomor 1 Tahun} 2015 Tentang Ketertiban Umum

Pasal 39 Ayat (1) Peraturan Daerah Kota Denpasar Nomor 1 Tahun 2015 Tentang Ketertiban Umum melarang perbuatan prostitusi, menawarkan dan/menyediakan diri sendiri untuk perbuatan prostitusi, menyuruh, memfasilitasi, membujuk, memaksa, menawarkan orang lain untuk melakukan prostitusi, dan memakai jasa prostitusi. Pasal 39 Ayat (3) Perda ini juga melarang menyediakan/mengusahakan tempat asusila dan/prostitusi. Apabila ketentuan dalam pasal 39 ini dilanggar maka diancam dengan pidana kurungan makdimsl 6 (enam) bulan atau denda maksimal Rp. 50.000.000 sebagaimana diatur dalam pasal 58 Perda ini.

Peraturan Daerah Kabupaten Badung Nomor 7 Tahun 2016 Tentang Ketertiban Umum dan Ketenteraman Masyarakat

Pasal 26 Peraturan Daerah Kabupaten Badung Nomor 7 Tahun 2016 Tentang Ketertiban Umum dan Ketenteraman Masyarakat melarang menawarkan dan/atau menyediakan diri sendiri untuk perbuatan prostitusi, menyuruh, memfasilitasi, membujuk, memaksa orang lain untuk melakukan perbuatan prostitusi, dan memakai jasa prostitusi. Bagi pelanggarnya akan dipidana dengan pidana kurungan maksimal 6 (enam) bulan atau pidana denda maksimal $\mathrm{Rp}$. 50.000.000,00 sebagaimana diatur dalam Pasal 32 Perda ini.

Aturan dalam beberapa Peraturan Daerah di Indonesia menunjukkan bahwa perbuatan prostitusi dilarang dan diancam dengan sanksi pidana di beberapa daerah di Indonesia. Pemerintah daerah melalui Perda juga nampaknya berupaya memberantas prostitusi dengan mengancam pidana bagi tidak hanya mucikari tapi juga PSK dan pengguna jasa prostitusi.

Oksidelfa Yanto menyatakan bahwa beberapa daerah mengeluarkan Perda (Peraturan Daerah) 
mengenai kegiatan prostitusi, namun minim implementasi membuat Perda tersebut hanya menjadi hiasan kertas. Penyebab lainnya ialah tidak konsistennya dalam perapannya. Contoh Perda yang dapat menjerat pidana PSK maupun pemakai jasanya misalnya pasal 42 ayat (2) Perda DKI Jakarta No. 8 Tahun 2007 Tentang Ketertiban Umum, "Setiap orang dilarang: 1) menyuruh, memfasilitasi, membujuk, memaksa orang lain untuk menjadi penjaja seks komersial; 2) menjadi penjaja seks komersial; c) memakai jasa penjaja seks komersial. "Orang yang melanggar ketentuan ini di-kenakan ancaman pidana kurungan paling singkat 20 hari dan paling lama 90 hari atau denda paling sedikit $\mathrm{Rp}$ $500.000,00$ dan paling banyak Rp 30 juta (pasal 61 ayat (2) Perda DKI 8/2007). Praktiknya, para PSK yang beroperasi di panti pijat dan hiburan malam justru banyak tidak ditindak. (Ibid:195)

Perda sebagai peraturan daerah tentu memiliki keberlakuan tersendiri yang hanya berlaku di daerahnya saja. Penanganan prostitusi berdasarkan aturan Perda tentunya sangat bergantung kepada lokasi daerah yang menjadi tempat perkara, karena tidak semua daerah memiliki Perda tentang prostitusi. Penegakan hukum terhadap prostitusi melalui aturan Perda hanya bersifat territorial, sehingga tidak jarang dapat menimbulkan diskriminasi dan ketidakdilan, karena tiap daerah memiliki budaya hukum yang berbeda, baik dalam hal pertanggungjawaban pidana prostitusi maupun pemidanaan pelaku prostitusi. (Trias Palupi Kurnianingrum, 2019:4). Sebagaimana yang telah diuraikan Perda juga dapat bertentangangan dengan KUHP yang tidak mengatur mengenai pemidanaan terhadap PSK dan Pengguna jasa prostitusi.

KUHP tidak mengatur pertanggungjawaban pidana terhadap PSK dan pengguna jasa prostitusi online. KUHP hanya mengatur prostitusi dalam Pasal 296 KUHP dan Pasal 506 KUHP, namun hanya dapat dikenakan terhadap mucikari. Apabila dikaji peraturan di luar KUHP terkait prostitusi online, PSK dan pengguna jasa dapat dijerat dengan menggunakan Pasal 45 Ayat (1) UU ITE, namun berlaku terbatas hanya jika PSK/ Pengguna jasa mendistribusikan, mentransmisikan, menjadikan/membuat dapat diaksesnya perbuatan prostitusi melalui media/ informasi elektronik.

Dalam prakteknya, kasus prostitusi online yang berkaitan dengan perdagangan orang, mucikari dalam kasus tersebut dapat dijerat dengan undang-undang perdagangan orang. Apabila korbannya adalah seorang anak, mucikari juga dapat dijerat dengan undang-undang perlindungan anak, namun perlu ditegaskan bahwa undang-udang perdagangan orang dan perlindungan hanya mengatur terkait mucikari yang memperdagangkan orang dan memprostitusikan anak dibawah umur. Perda yang mengatur pemidanaan terhadap prostitusi juga berlaku terbatas pada daerah yang mengatur prostitusi saja sehingga dapat diketahui bahwa aturan prostitusi di Indonesia masih lemah terutama terkait pemidanaan PSK dan penggunajasa prostitusi.

\section{Politik Hukum Pemberantasan Prostitusi, Khususnya Terkait Kriminalisasi PSK (Pekerja Seks Komersial) dan Pengguna Jasa Prostitusi Online di Indonesia}

Politik hukum dalam pemberantasan kejahatan tentu memiliki peranan yang sangat besar, karena pemberantasan kejahatan melalui penegakan hukum harus berdasarkan hukum yang sesuai dengan asas legalitas. Begitupula dalam kasus prostitusi online di Indonesia. Sebagaimana yang disebutkan oleh Frank E. Hagan bahwa prostitusi disebut dengan profesi tertua di dunia. Kejahatan prostitusi memang telah ada sejak dulu, namun hingga kini belum bisa diberantas. Kejahatan ini terus berkembang dan hingga kini seiring dengan perkembangan teknologi dapat sangat mudah dilakukan melalui media online. Pemberantasan kejahatan tentu harus dilakukan sampai pada akar -akarnya. Dalam hal ini pemberantasan atau penegakan hukum prostitusi online tidak tepat jika hanya mempidana mucikari saja. Pemberantasan kejahatan dapat efektif ketika semua pihak dalam kejahatan itu dapat dipidana sehingga dapat memberikan efek jera dan fungsi pencegahan.

KUHP tidak mengatur tentang pemidanaan PSK dan pengguna jasa prostitusi. KUHP hanya mengatur tentang pemidanaan mucikari saja, sehingga dalam konteks ini PSK dan pengguna jasa prostitusi tidak dapat dipertanggungjawabkan secara pidana dengan KUHP. Pasal perzinahan dalam KUHP juga bukan merupakan undangundang yang tepat. Ketika prostitusi dilakukan dengan media online (prostitusi online) dapat digunakan UU ITE, meskipun pengaturan dalam hal ini sangat umum yakni mengancam perbuatan yang mengandung muatan kesusilaan yang dilakukan secara online. Sebaliknya kejahatan 
prostitusi yang tidak dilakukan secara onlinetentu tidak bisa dijerat dengan pasal ini.

Beberapa perda di Indonesia juga telah memuat tentang pengaturan larangan prostitusi namun pengaturannya bersifat territorial saja karena tidak semua daerah mengeluarkan atau membuat perda ini. Prakteknya prostitusi onlinejuga dapat dijerat dengan pasal dalam UU Perdagangan orang dan UU Perlindungan anak namun hanya dapat digunakan jika PSK dalam kasus prostitusi tersebut diperdagangkan atau jika korban yang dijadikan PSK adalah anak dibawah umur. Hal ini sebagaimana yang telah diuraikan dalam uraian 4.1 menunjukkan bahwa pengaturan prostitusi onlinebelum tegas sehingga perlu dilakukan politik hukum pidana atau kebijakan hukum pidana dalam mengkriminalisasi PSK dan pengguna jasa prostitusi khususnya dalam tulisan ini adalah prostitusi onlinesehingga prostitusi khususnya prostitusi onlinebisa diberantas.

Kriminaliasi PSK dan pengguna jasa prostitusi khususnya dalam tulisan ini adalah prostitusi onlinesangat diperlukan karena pelaku kejahatan ini merupakan sebuah sistem. Mucikari, PSK, dan pengguna jasa prostitusi adalah pelaku. PSK dan pengguna jasa juga memiliki andil yang besar sehingga dapat terwujudnya delik prostitusi onlineini. Terdapat pandangan bahwa prostitusi onlineadalah kejahatan tanpa korban. Hal ini tentu tidaklah tepat karena korban utama adalah masyarakat. Pelaku terkait konteks ini juga menjadi korban, terutama PSK.

Pemberantasan prostitusi onlineharus dimulai dari substansi hukumnya dahulu, lalu selanjutnya dari struktur hukum dan budaya hukum sebagaimana teori sistem hukum dari Lawrence M. Friedman. Substansi hukum berupa peraturan perundang-undangan yang mengatur prostitusi onlineharus diperkuat, terutama dalam KUHP sebagai hukum pidana nasional Indonesia dan sumber hukum utama di bidang hukum pidana. Politik hukum, khsusnya politik hukum pidana sangat diperlukan dalam hal ini.

Pembentukan hukum dalam hal ini dapat berupa pembentukan atau pembuatan hukum baru dan dapat pula berupa penggantian hukum lama (revisi). Pembentukan hukum ini pada dasarnya tetap harus berpijak, berlandaskan, dan dilaksanakan dalam kerangka politik hukum nasional, yang sesuai dengan pancasila dan konstitusi Negara Republik Indonesia. Politik hukum sangat perlu diterapkan dalam pembentukan peraturan perundang-undangan di berbagai bidang hukum, salah satunya yakni di bidang hukum pidana untuk mengatasi kasus prostitusi yang hingga saat ini masih marak terjadi di Indonesia.

Yesmil Anwar menyatakan bahwa kebijakan yang dapat dilakukan untuk mengatasi prostitusi secara garis besar terdiri dari legalisasi yakni penutupan praktik prostitusi, kriminalisasi yakni mengkriminalkan pelaku prostitusi, dan abolisi yakni menghapus sampai ke akar-akarnya praktik prostitusi, karena prostitusi dianggap sebagai perbudakan. Indonesia termasuk negara yang menerapkan kebijakan kriminalisasi, meskipun pada praktiknya prostitusi tidak pernah habis dan bahkan kian hari tumbuh subur (Anwar, 2009). Hal ini menunjukkan bahwa perlu dilakukan pengaturan untuk penegakan hukum pidana, salah satunya melakukan pembaharuan hukum pidana.

Pembaharuan hukum terhadap produk hukum berupa perundang-undangan yang telah usang, tidak sesuai dan tidak mencerminkan hukum yang responsif tentu perlu diadakan perubahan sebagaimana yang menjadi lingkup dari politik hukum, demikian halnya terhadap KUHP Indonesia. Searah dengan pandangan Mochtar Kusumaatmadja yang menyebutkan bahwa politik hukum adalah kebijakan hukum dan perundangundangan, dalam rangka pembaruan hukum, serta pandangan dari Bellefroid yang menyatakan bahwa politik hukum menyelidiki perubahanperubahan yang harus diadakan pada hukum yang ada saat ini. Pembaharuan hukum dalam konteks ini penting dilakukan.(Latif \& Ali, 2011)

Dalam perkembangan hukum pidana seiring dengan perkembangan teknologi, pembaharuan hukum pidana menjadi hal yang penting dalam reformasi dan pembangunan hukum pidana ke arah yang lebih baik. Pembaharuan hukum ini diperlukan sebagai suatu upaya dalam reorientasi dan reformasi hukum pidana yang juga meliputi nilai-nilai yang ada dalam masyarakat yang sesuai dengan volk geist (jiwa bangsa) yang mencerminkan keadilan, kemanfaatan, dan kepastian hukum. Sebagaimana yang telah kita ketahui KUHP Indonesia yang hingga kini masih berlaku di Indonesia, sebagai warisan zaman kolonial tentu tidak sesuai dengan kepribadian bangsa Indonesia. Prostitusi tentu sangat bertentangan dengan budaya Indonesia.

Prostitusi sangat berlawanan dengan budaya adat ketimuran yang sangat menghormati kedudukan perempuan dan sangat menyoroti kesusilaan dan kesopanan dalam kehidupan 
bermasyarakat. Dalam rangka untuk mencapai ius constituendum, pembaharuan hukum pidana (KUHP) sangat penting untuk dilakukan untuk menghasilkan hukum yang efektif dan responsif.

Saat ini KUHP dan Undang-undang diluar KUHP hanya dapat menjerat penyedia tempat dan atau mucikarinya saja sedangkan untuk pengguna dan untuk pekerjanya tidak dapat dipidana. Perda yang mengatur tentang larangan praktek prositusi juga tidak efektif, karena tidak semua daerah memiliki perda ini. Penegakan hukum terhadap pelacuran melalui peraturan daerah hanya bersifat teritorial karena pengaturannya berada pada peraturan daerah masing-masing.

Adapun dalam menanggulangi pelacuran, pemerintah daerah menggunakan kebijakan pengaturan yang diwujudkan dalam bentuk lokalisasi atau tempat pelacuran legal. Lokalisasi ini bertujuan untuk mengumpulkan tempat kegiatan pelacuran beserta dampak negatifnya dalam suatu tempat. Kebijakan lokalisasi ini secara tidak langsung memuat pemahaman bahwa pemerintah melegalkan praktek pelacuran yang bertentangan dengan norma agama, perdagangan orang khususnya wanita dan juga Pasal 296 KUHP terkait tempat pelacuran. Kebijakan lokalisasi ini sama saja memberikan seseorang kesempatan untuk melakukan perzinahan yang legal menurut hukum, sehingga sudah seharusnya setiap subyek dalam pelacuran yang memiliki keterkaitan dapat mempertanggungjawaban perbuatannya. Hal ini perlu ditindak dengan merumuskan aturan pidana tentang pelarangan prostitusi bagi mucikari, PSK dan pengguna jasa prostitusi. (Anindia \& Sularto, 2019)

Peraturan prostitusi yang diatur dalam KUHP masih bersifat diskriminasi karena hanya mengatur pemidanaan mucikari saja. Pengaturan ini juga tidak efektif karena sebagai sebuah sistem, PSK dan pengguna jasa prostitusi juga harus dipertanggungjawabkan secara pidana. Sebagai sebuah sistem, jika PSK dan pengguna prostitusi dikriminalisasikan atau dipenalisasikan dengan memberikan anacaman pidana maka prostitusi onlinedapat diberantas. Tanpa PSK dan pengguna jasa prostitusi akan lebih mengefektifkan pemeberantasan prostitusi termasuk prostitusi onlinedi Indonesia. Pembaharuan KUHP dengan mengkriminalisasi PSK dan pengguna prostitusi, khususnya prostitusi online urgen untuk dilakukan.

Menurut Barda Nawawi Arief pembaharuan hukum pidana (penal reform) adalah bagian dari kebijakan/politik hukum pidana (penal policy) dengan membentuk peraturan yang baik. (Arief, 2008) Pembaharuan KUHP Indonesia harus berpijak dan dibentuk berdasarkan politik hukum yakni politik hukum pidana. Pembaharuan KUHP Indonesia menemui berbagai kendala yang menyebabkan hingga saat ini rancangan tersebut belum disahkan dan diberlakukan. Rancangan KUHP ini terus diperbaharui dengan berbagai konsep yang diharapkan mampu efektif menanggulangi kejahatan serta memberikan keadilan dan perlindungan.

Melalui politik hukum, badan legislatif/ legislator memilih dan menentukan pilihan terhadap berbagai hal/tindakan/perbuatan/ keputusan dalam berbagai alternatif-alternatif yang ada dalam proses pembentukan hukum yang sesuai dengan konstitusi dan pancasila sebagai dasar negara Indonesia. Tindakan memilih ini juga harus disertai pertimbangan untuk kepentingan rakyat, bukan untuk kepentingan politik kelompok tertentu. Sangat diharapkan dengan pembaharuan hukum yang berdasarkan kepentingan rakyat, hukum yang dibentuk dapat mencerminkan perasaan hukum masyarakat sehingga pembangunan hukum nasional tercapai sesuai dengan rasa keadilan masyarakat.

Pembentukan hukum atau pembaharuan hukum dalam kerangka politik hukum juga harus diterapkan sesuai dengan konstitusi dan pancasila sebagai dasar negara Indonesia. Pancasila sebagai paradigma pembangunan hukum yang menentukan kaidah penuntun tertentu dalam pembentukan hukum. Hal ini juga sebagai sebuah konsekuensi bahwa pancasila merupakan sumber di dalam berbagai hukum yang ada. Mengenai kedudukannya, pancasila memiliki kedudukan yang paling tinggi, yakni sebagai cita-cita serta pandangan hidup bangsa dan pandangan hidup Negara Republik Indonesia.

Dalam kerangka politik hukum, pemberantasan prostitusi online perlu dilakukan pembaharuan hukum pidana dengan mensinergikan dengan Konsep rancangan KUHP yakni dengan mengkriminalisasi atau membuat aturan atau mengatur pemberian ancaman pidana terhadap PSK dan pengguna jasa prostitusi online (penalisasi) agar bisa dipertanggungjawabkan secara pidana.

Dalam perkembangan hukum pidana, seiring dengan perkembangan teknologi serta kebutuhan hukum yang kian meningkat, pembaharuan hukum pidana menjadi hal yang penting dalam 
reformasi dan pembangunan hukum pidana ke arah yang lebih baik. Pembaharuan hukum ini diperlukan sebagai suatu upaya dalam reorientasi dan reformasi hukum pidana yang juga meliputi nilai-nilai yang ada dalam masyarakat yang sesuai dengan volk geist (jiwa bangsa) yang mencerminkan keadilan, kemanfaatan, dan kepastian hukum bagi masyarakat Indonesia. Mengingat bahwa teknologi semakin canggih dan berkembang salah satunya dengan adanya media kejahatan dengan online ini, maka hukum haruslah dinamis dengan melakukan perubahanperubahan sejalan dengan perkembangan zaman, teknologi, kebutuhan hukum, dan dinamika kehidupan masyarakat.

Pembaharuan hukum pidana khususnya mengenai hukum pidana materiil (substantif) merupakan hal yang penting dan mendasar, karena KUHP sekarang tidak dapat lagi memenuhi kebutuhan hukum dan rasa keadilan masyarakat Indonesia.

Pembaharuan dan pembangunan sistem hukum nasional yang berjalan sangat lamban mengarah pada anggapan bahwa, pembaharuan hukum pidana Indonesia khususnya sistem hukum nasional yang berlandaskan aspek ke Indonesiaan bukanlah hal yang mudah. Perlu dipahami bahwa, menurut Barda Nawawi Arief, membangun atau melakukan pembaharuan hukum (law reform, khususnya "penal reform") pada hakikatnya adalah "membangun/memperbaharui pokokpokok pemikiran/konsep/ide dasarnya", bukan sekedar memperbaharui/mengganti perumusan pasal (undang-undang) secara tekstual. Oleh karena itu, kajian atau diskusi tekstual mengenai konsep RUU KUHP harus disertai dengan diskusi konseptual.(Ibid:1) Berdasarkan hal ini dapat diketahui bahwa, pembaharuan hukum pidana dilakukan secara total, bukan merupakan tambal sulam dengan hanya mengganti secara tekstual (substansi) dari Undang-Undang. Secara total disini artinya yakni, bahwa yang diperbaharui adalah konsepnya, ide-idenya, pokok pikirannya, gagasan, pandangan, nilai-nilainya yang diarahkan pada karakter, kepribadian bangsa Indonesia dan tetap mengacu pada Pancasila. Pembaharuan hukum dalam hal ini untuk mengefektifkan penegakan hukum maka dapat dimaknai sebagai kebijakan untuk memperbaharui substansi hukum.

Barda Nawawi Arief juga menyatakan bahwa, makna dan hakikat reformasi atau pembaharuan KUHP :
KUHP merupakan suatu sistem hukum, khususnya merupakan sistem hukum pidana (penal sistem) atau sistem pemidanaan (sentecing sistem). Oleh karena itu pembaharuan KUHP pada hakikatnya adalah pembaharuan sistem hukum pidana/sistem pemidanaan.

KUHP Pada hakikatnya merupakan pembaharuan nilai budaya hukum/ide dasar. (Arief, 2008)

Hal ini menunjukkan bahwa, pembaharuan hukum tidak hanya merupakan pembaharuan secara substantif, tapi merupakan pembaharuan sistem hukum, yang juga meliputi pembaharuan struktur hukum dan budaya hukum.

Sebagaimana yang telah kita ketahui, bahwa terdapat 3 (tiga) masalah pokok dalam hukum pidana, yaitu tindak pidana, kesalahan, dan pidana, jika dikaji 3 masalah pokok inilah yang kemudian menjadi fokus dalam Rancangan KUHP Indonesia. Barda Nawawi Arief menyatakan bahwa :

Konsep rancangan KUHP Baru disusun dengan bertolak pada tiga materi/substansi/ masalah pokok dalam hukum pidana, yaitu :

Masalah tindak pidana;

Masalah kesalahan atau pertanggungjawaban pidana, dan

Masalah pidana dan pemidanaan (Arief 2005).

Prostitusi dalam fokus rancangan tersebut adalah terkait dengan masalah tindak pidana yang perlu direkonstruksi kembali dengan mengkriminalisasi dan penalisasi PSK dan pengguna jasa prostitsui. Pembaharuan hukum pidana juga meliputi 3 sub sistem yakni substansi hukum, struktur hukum, dan budaya hukum sebagaimana dalam teori sistem hukum dari Lawrence Friedman. Sebagaimana yang telah diraikan di dalam Bab II dapat diketahui bahwa berdasarkan uraian dari Lawrence M. Friedman terkait sistem hukum tersebut (substansi hukum, struktur hukum, dan budaya hukum) dapat diketahui bahwa sistem hukum terdiri dari sub sistem-sub sistem hukum yang saling berinteraksi antara substansi hukum (legal substance), Struktur hukum (legal structure) dan Budaya hukum (legal culture). Ketiga sub sistem ini harus bersinergi dalam melakukan penegakan hukum terkait prostitusi online.

Terkait dengan substansi hukum, perumusan norma terkait prostitusi online perlu dituangkan 
dalam Rancangan KUHP yang pada intinya mengatur sanksi pidana terhadap PSK dan pengguna jasa prostitusi. Tindakan ini perlu dilakukan untuk memberantas prostitusi online di Indonesia. Perumusan norma dalam konteks PSK yang melakukan prostitusi onlinedapat dirumuskan bahwa, "Barang siapa yang melakukan perbuatan cabul atau persetubuhan dengan orang lain dan menerima pembayaran dengan persetujuannya serta bertransaksi melalui media atau informasi elektronik diancam dengan pidana pidana penjara selama ........ dan denda sebesar........". Perumusan norma bagi pengguna jasa prostitusi dapat diatur atau dirumuskan sebagai berikut, "Barang siapa yang memanggil, mengajak, memesan, menerima seseorang secara online melalui media elektronik untuk melakukan perbuatan cabul atau persetubuhan secara komersial diancam dengan pidana penjara selama ........... dan denda sebesar.........".

Kriminalisasi ini penting dilakukan dengan mengaturnya di dalam Rancangan KUHP karena KUHP yang berlaku saat ini adalah peninggalan Kolonial Belanda yang tentu tidak sesuai dengan adat, budaya bangsa Indonesia. Kriminalisasi perlu dilakukan di dalam KUHP karena KUHP adalah hukum pidana material yang menjadi sumber dari undang-undang lainnya. KUHP juga memiliki nilai keberlakuan yang tinggi sebagai undang-undang jika dibandingkan dengan membentuk Perda yang tidak efektif dan nantinya akan bertentangan dengan KUHP.

\section{SIMPULAN}

KUHP tidak mengatur pemidanaan terhadap PSK dan Pengguna jasa prostitusi online, sehingga tidak bisa dipertanggungjawabkan secara pidana. Apabila dikaji peraturan di luar KUHP terkait prostitusi online, PSK dan pengguna jasa dapat dijerat dengan menggunakan Pasal 45 Ayat (1) Undang- undang RI No. 19 Tahun 2016 Tentang Perubahan Atas UndangUndang Nomor 11 Tahun 2008 Tentang Informasi dan Transaksi Elektronik, namun aturan ini masih bersifat umum yang mengatur larangan yang melanggar kesusilaan. Pengaturan prostitusi juga dapat ditemukan dalam Peraturan Daerah (Perda), namun tidak semua daerah memiliki atau mengeluarkan Perda tentang Prostitusi, sehingga keberlakuannya terbatas pada territorial.

Politik hukum yang dapat diambil adalah dengan pembaharuan hukum pidana dengan mensinergikan dengan Konsep rancangan KUHP yakni dengan mengkriminalisasi atau membuat aturan atau mengatur pemberian ancaman pidana terhadap PSK dan pengguna jasa prostitusi onlineagar bisa dipertanggungjawabkan secara pidana (penalisasi).

\section{DAFTAR PUSTAKA}

Anindia, I. A., \& Sularto, R. B. (2019). Kebijakan Hukum Pidana Dalam Upaya Penanggulangan Prostitusi Sebagai Pembaharuan Hukum Pidana. Jurnal Pembangunan Hukum Indonesia, 1(1). Retrieved from https://doi.org/10.14710/ jphi.v1i1.18-30

Anwar, Y. (2009). Saat menuai kejahatan: sebuah pendekatan sosiokultural kriminologi, hukum, dan HAM. Bandung: Refika Aditama.

Arief, B. N. (2008). Bunga rampai kebijakan hukum pidana: Perkembangan penyusunan konsep KUHP baru. Jakarta: Kencana.

Arief, B. N. (2005). Pembaharuan hukum pidana dalam perspektif kajian perbandingan. Bandung: Citra Aditya Baktim.

Hagan, F. E. (2013). Kriminologi (Teori, Metode, dan Perilaku Kriminal). Terj. AK Anwar. Jakarta: Kencana

Kurnianingrum, T. P. (2019). Politik Hukum Terhadap Tindak Pidana Prostitusi. Bidang Hukum Info Singkat Kajian Singkat Terhadap Isu Aktual dan Strategis. 9(1). Retrieved from https:// berkas.dpr.go.id/puslit/files/info singkat/Info \% 20Singkat-XI-1-I-P3DI-Januari-2019-214.pdf

Latif, A., \& Ali. H. (2011). Politik Hukum. Jakarta: Sinar Grafika.

Sianturi, S. R. (1983). Tindak Pidana di KUHP berikut uraiannya. Bandung: Alumni.

Soesilo (R.). (1976). Kitab undang-undang hukum pidana (KUHP): serta komentar-komentarnja lengkap pasal demi pasal. Politeia.

Syaukani, I. (2010). A. Ahsin Thohari. Dasar-Dasar Politik Hukum.

Yanto, O. (2016). Prostitusi Online sebagai Kejahatan Kemanusiaan terhadap Anak: Telaah Hukum Islam dan Hukum Positif. AHKAM: Jurnal Ilmu Syariah, 16(2). Retrieved from http:// dx.doi.org/10.15408/ajis.v16i2.4449 